\title{
al-Munqiz Min al-Dhalal: Sebuah Upaya Pembacaan Epistemologis
}

\author{
Kusroni \\ Sekolah Tinggi Agama Islam Al Fithrah, Surabaya \\ Email : kusroni8$\overline{7}$ live.com
}

\begin{abstract}
ABSTRAK
Abu Hamid al-Ghazali dikenal sebagai tokoh Islam dengan julukan Hujjatul Islam. Ia dikenal sebagai ulama yang multi talenta, dan menghasilkan berbagai karya otoritatif dalam berbagai cabang keilmuan Islam, mulai dari Teologi, Fiqih, Ushul Fiqh, Filsafat, dan Tasawuf. Hal yang menarik dari sosok al-Ghazali ini adalah bahwa ia menulis sebuah karya otobiografi yang menggambarkan proses perjalanan panjangnya dalam dunia intelektual maupun spiritual.
\end{abstract}

Kata kunci: al-Ghazali, Epistemologis, al-Munqiz

\section{Prolog}

Kitab al-Munqiz min al-Dhalal merekam dengan detail kegelisahan intelektual dan spiritual al-Ghazali ${ }^{1}$ selama pengembara-

1 Abu Hamid Muhammad bin Muhammad bin Muhammad al-Ghazali lahir di Thus, salah satu daerah daerah di Khurasan, Iran pada $450 \mathrm{H} / 1058 \mathrm{M}$. Sejak kecil ia belajar ilmu fiqh pada Imam Ahmad bin Muhammad al-Radzikani, kemudian pindah ke Jurjan untuk nyantri pada Imam Abi Nasr al-Isma'ily. Setelah itu, alGhazali pindah ke Naisabur, belajar pada Imam Haramain al-Juwaini. Di sini ia mulai mengenal tasawuf dan filsafat. Setelah Juwaini tutup usia pada 477, tujuh tahun berikutnya al-Ghazali pergi ke Irak, mengajar di Madrasah Nidzamiyyah. Di madrasah milik Wazir Nidzam al-Mulk (1018-1018 M) inilah popularitas dan kapasitas keilmuan al-Ghazali mulai diperhitungkan banyak orang. Karir intelektual al-Ghazali semakin menunjukkan kematangannya setelah ia banyak menulis tentang fiqh, teologi, filsafat dan tasawuf. Ia tergolong ulama yang sangat produktif. Ibnu Qadli Syuhbah al-Dimsyiqi, pengarang kitab "Thabaqat alSyafiiyyah", mencatat ada sekitar 60 kitab yang ditulis al-Ghazali. Sementara alZabidi, pensyarah kitab Ihya', menyebut ada sekitar 80 kitab dan risalah yang ditulis al-Ghazali. Ketika usianya mulai beranjak senja, Al-Ghazali pulang ke tanah kelahirannya, sampai beliau wafat pada $505 \mathrm{H} / 1111 \mathrm{M}$. 
annya dalam dunia akademik. Dalam kitab ini, al-Ghazali menceritakan dengan jujur bahwa proses pencarian "kebenaran" adalah perkara yang tidak mudah. Ia butuh pengorbanan, keberanian, kejujuran serta kesungguhan. Tulisan ini berupaya melakukan pembacaan epistemologis al-Ghazali melalui karyanya, al-Munqiz min al-Dhalal.

al-Ghazali menjelaskan bahwa samudera intelektual dan pemikiran keagamaan dengan berbagai perbedaan dan golongangolongannya sangatlah luas dan ganas. Sedikit sekali orang selamat darinya. Masing-masing kelompok mengklaim kebenarannya masing-masing. Sejak usia belia, sebelum usia 20 tahun, al-Ghazali selalu gelisah dan sering mempertanyakan segala sesuatu. Kegelisahan ini membuatnya selalu menyelami samudera intelektual yang luas itu. Dengan keberanian yang tinggi ia menceburkan diri ke dalam samudera intelektual itu, mempelajari secara mendalam ideologi dari setiap pemikiran dan kelompok yang berkembang pada saat itu, untuk kemudian berusaha membedakan mana yang benar dan mana salah, mana yang sesuai sunnah dan mana yang bid'ah. ${ }^{1}$

Untuk itu ia menyelam ke dalam pemikiran dan ideologi aliran Batiniyah, mempelajari apa yang melandasi kebatinan mereka. Ia juga masuk ke dalam ideology dan pemikiran Dhahiriyah untuk mengetahui landasan-landasan pemikiran mereka. al-Ghazali juga menyelam ke

1 Abu Hamid Muhammad bin Muhammad al-Ghazali, al-Munqiz min al-Dhalal wa al-Mufsih bi al-Ahwal, (Beirut: Dar al-Minhaj, 2013), Cet.I, 44 
dalam samudera Filsafat, mempelajari seluk beluk pemikiran mereka. Kemudian ia masuk ke ranah Teologi (ilmu Kalam), dan berusaha mendalami seluk beluk perdebatan-perdebatan mereka. al-Ghazali kemudian mendalami Tasawuf dan bergaul dengan para sufi, untuk mengetahui secara mendalam rahasia-rahasia kesufian mereka. Termasuk bergaul dengan orang-orang zindiq, untuk mengetahui apa yang membuat mereka menjadi zindiq. ${ }^{1}$

Ia mengakui, bahwa kehausannya akan ilmu pengetahuan dan mencari jalan kebenaran ini adalah fitrah dari Allah ta'ala yang tertanam dalam dirinya sejak usia belia, bukan semata-mata atas kehendak(ikhtiyar)nya sendiri. Hal ini membuatnya selalu berusaha melapaskan diri dari belenggu taqlid, dan membebaskannya dari jeratan tradisi dan kepercayaan yang sudah mentradisi sejak usianya masih muda.

Kesadaran seperti ini timbul setelah ia sama sekali tidak melihat perubahan apa-apa pada anak-anak orang Nasrani maupun Yahudi. Mereka akan selamanya tumbuh menjadi Nasrani maupun Yahudi, dan seterusnya. Sebagaimana yang disitir oleh hadits Nabi SAW: "Setiap anak terlahir dalam keadaan fitrah. Orang tuanyalah yang telah menjadikan ia Yahudi, Nasrani dan Majusi". ${ }^{2}$ Oleh karena itu, tergerak dalam hati al-Ghazali untuk melakukan lompatanlompatan dan pilihan-pilihan sendiri, berdasarkan pencarian dan upaya pribadi.

\footnotetext{
1 Ibid. 45-46

2 Ibid., 46
} 


\section{Kegelisahan Intelektual-Spiritual al-Ghazali}

Seperti yang dituturkan sendiri oleh al-Ghazali, bahwa ia menulis kitab Munqidz ini, atas permintaan dari seorang kawan seagama (al-akh fi al-din) yang bertanya tentang puncak dari ilmu pengetahuan (ghayat al-ulum) dan rahasia-rahasia (asrar)nya. Dalam upayanya mencari hakikat kebenaran (haqa'iq al-umur), al-Ghazali mula-mula mengharuskan dirinya mencari tau apa itu hakikat ilmu pengetahuan? Ia menyimpulkan bahwa pengetahuan yang benar (alilm al-yaqin) adalah sesuatu yang dengannya apa-apa yang diketahui (al-ma'lum) bisa tersingkap dengan jelas tanpa ada keraguan ataupun kesalahan. Pengetahuan yang hakiki harus bisa menumbuhkan keyakinan sedemikian rupa, sehingga walaupun ada seorang hebat (misalnya) yang mampu merubah tongkat menjadi ular, keyakinan tersebut tidak akan goyah. Pengetahuan inilah yang benar. Jika tidak demikian, maka pengetahuan tersebut tidak bisa dijadikan pegangan. ${ }^{1}$

Lalu, al-Ghazali melakukan pengamatan (al-tafstisy) terhadap pengetahuan-pengetahuannya. al-Ghazali menyimpulkan bahwa ternyata ia tidak memiliki pengetahuan yang meyakinkan (alilm al-yaqin) sebagaimana disimpulkan sebelumnya, kecuali pengetahuan dari hasil pengamatan empiris (hissiyyat) dan rasionalis (dharuriyyat). Dengan demikian, ia berkeyakinan bahwa persoalan yang rumit (al-musykilat) harus dipecahkan melalui pengamatan empiris dan berbasis rasionalitas. Akan tetapi pada fase ini ia

1 Ibid., 47 
menjadi ragu, apakah dengan bersandarkan pada empirisme dan rasionalisme ia akan memperoleh pengetahuan yang meyakinan? Dari sini al-Ghazali mulai kemudian mencoba melakukan pengujianpengujian (al-tajribah). ${ }^{1}$

Pertama-tama ia menguji validitas data-data empiris (hissiyyat), semisal, data yang diterima indra penglihat (mata). Dalam hal ini al-Ghazali memisalkan dua contoh. Pertama, pandangan mata terhadap bayang-bayang (al-dhill) yang tampak diam tak bergerak, ternyata faktanya tidak demikian. Ia bergerak sedikit demi sedikit, sehingga akhirnya bergeser sama sekali dari tempat asalnya. Kedua, mata seringkali melihat bintang-bintang di atas langit. Menurut penglihatan, bintang-bintang itu terlihat kecil, sekecil uang logam. Namun, berdasarkan teori ilmu Geometri (aladillah al-handasiyyah), ternyata bintang-bintang itu jauh lebih besar dibanding bumi. Dari sini tampak bahwa, pada faktanya, datadata yang diterima oleh inderawi sering kali menipu, bertolak belakang dengan fakta sesungguhnya. ${ }^{2}$

Dari kegagalan menggunakan pendekatan empiris di atas, alGhazali kemudian berpindah pada pendekatan rasionalisme. Menurut penganut rasionalisme, satu-satunya pengetahuan yang absah dan dapat dipercaya adalah pengetahuan yang dihasilkan akal (rasional). Contohnya, bilangan 10 pasti lebih besar dari bilangan 3 . Ada dan tiada, tidak mungkin bertemu dalam satu waktu, begitu

\footnotetext{
1 Abu Hamid Muhammad bin Muhammad al-Ghazali, al-Munqiz min al-Dhalal wa al-Mufsih bi al-Ahwal, (Beirut: Dar al-Minhaj, 2013), Cet.I., 48

2 Ibid., 49
} 
juga qadim (lampau/kekal) dan hadits (baru) tidak mungkin dilekatkan pada sesuatu dalam waktu bersamaan, dan seterusnya.

Akan tetapi empiris mengajukan bantahan. Bagaimana bisa dipastikan bahwa pendekatan rasionalitas lebih kuat daripada pendekatan empiris? Sebelum ada hukum rasional yang dipercaya adalah empiris, andai kata hukum rasional tidak muncul, niscaya empiris masih dipercayai. Bisa jadi, suatu saat nanti ada hukum lain yang bisa mematahkan hukum rasional. Tidak adanya hal itu pada saat ini, bukan berarti menafikannya selama-lamanya (adamu tajalliyyi dzalikal idrak, la yadullu alastihalatihi).

Hukum empiris memperkuat argumentasi bantahannya dengan mengemukakan tentang mimpi. Bukankah apa yang dilihat dalam mimpi benar-benar terjadi? Namun pada saat terbangun, baru disadari bahwa semua hanya mimpi dan ilusi. Lalu, bagaimana bisa dipastikan baik dengan hukum empiris dan rasionalis, bahwa apa yang diyakini adalah benar untuk saat ini?

Empirisme dan rasionalisme selamanya akan berperang dan saling menyalahkan. Keduanya tidak dapat bertemu dan dipertemukan. Pada fase ini, terjadi kebuntuan dan kegamangan antara pilihan rasional dan empirikal yang terjadi pada al-Ghazali. Ia menjadi diliputi keragu-raguan. Ia sudah berusaha menghilangkannya, namun rupanya tidak mudah, karena harus membangun argumenasi yang kuat, sedangkan argumen harus dibangun atas dasar hukum-hukum yang logis-rasionalis. Jika usaha terakhir ini saja tidak bisa diterima, maka jalan menuju kebenaran sejati telah 
tertutup. Hampir dua bulan lamanya al-Ghazali mengalami kondisi ini. Dalam dua bulan itu ia mengalami keadaan seperti apa yang dialami kaum sofisme (safsatah) Yunani ${ }^{1}$.

Hingga pada akhirnya, Allah ta'ala menyembuhkan hati alGhazali dari "penyakit" keraguan yang menyelimutinya dengan melalui pancaran Cahaya-Nya. Hati dan pikirannya menjadi jernih dan seimbang kembali sehingga mampu menerima pengertianpengertian rasional-logis. al-Ghazali berkeyakinan bahwa Cahaya Ketuhanan (Nur Ilahi) itulah yang menjadi kunci pembuka, termasuk untuk mencapai pada kebanyakan pengetahuan (ma'rifat), bukan dari susunan argumentasi-argumentasi yang rasional-logis. alGhazali menegaskan, siapa saja yang menyangka bahwa terbukanya hati dan fikiran (kasyaf) bisa diperoleh dengan melalui argumentasi rasional-logis, maka ia telah menyempitkan rahmat Allah yang luas. ${ }^{2}$

al-Ghazali kemudian menyinggung sabda nabi Muhammad saw. tatkala beliau ditanya tentang makna "al-syarh" (lapang) dalam ayat al-Qur' an surat al-An'am ayat 125 :

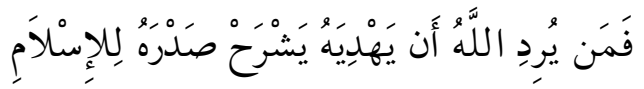

Nabi menjelaskan bahwa yang dimaksud dengan "lapang" dalam ayat itu adalah "Cahaya yang dipancarkan oleh Allah ke dalam hati, sehingga menjadi lapang". Apa tandanya? "menjauhi dunia yang semu, dan menghadapkan diri pada keabadian" Jawab

\footnotetext{
1 Abu Hamid Muhammad bin Muhammad al-Ghazali, al-Munqiz min al-Dhalal wa al-Mufsih bi al-Ahwal, (Beirut: Dar al-Minhaj, 2013), Cet.I, 51

2 Ibid., 52
} 
Rasul.

Cahaya itulah yang harus diupayakan untuk memperoleh kasyf, yaitu cahaya yang memancar pada saat-saat tertentu, sematamata atas kemurahan Allah ta'ala, sehingga harus terus berjaga dan bersiap untuk menyongsongnya. Sebagaimana sabda Nabi : "ada saat-saat tertentu bagi Allah untuk melimpahkan Karunia-Nya. Bersiaplah kalian untuk menerimanya." al-Ghazali menguraikan semua ini dimaksudkan agar senantiasa ada upaya dan usaha yang maksimal dalam mencari sesuatu sampai tidak ada lagi yang bisa dicari. ${ }^{1}$

\section{Kritik al-Ghazali atas Epistemologi Ilmu Pengetahuan}

Pasca "kesembuhan"nya dari "penyakit" keraguan, alGhazali kemudian melakukan klasifikasi terhadap kelompok ilmuan yang berupaya mencari kebenaran dengan keilmuan mereka di masa al-Ghazali hidup. Menurutnya, mereka terbagi dalam 4 kelompok, yaitu :

1. Para Teolog (al-mutakallimun), yaitu mereka yang mengklaim diri sebagai ahli penalaran (ra'yu) dan ahli debat (al-nadr).

2. Kelompok Batiniyah, yaitu mereka yang mengklaim diri sebagai pemilik tunggal perintah otoritatif (al-ta'lim) dan pewaris istimewa pengetahuan imam ma'shum.

3. Para Filosof, yaitu mereka yang mengklaim diri sebagai ahli logika dan argument (burhan).

1 Ibid., 53 
4. Para Sufi, yaitu mereka yang mengklaim sebagai orang-orang istimewa di sisi Tuhan, dan ahli musyahadah dan mukasyafah.

al-Ghazali yakin bahwa kebenaran yang meyakinkan tidak bergeser dari salah satu dari empat golongan ini. Karena mereka adalah orang-orang yang dengan sungguh-sungguh mencari kebenaran. Jika tidak, maka tidak ada harapan lagi untuk menggapai kebenaran. Sebab, tidak mungkin juga kembali kepada taqlid setelah menyatakan diri terlepas dari belenggunya. Karena salah satu syarat untuk taqlid adalah ketidaktauan. Jika telah faham, pecahlah kaca taqlid yang melingkupinya, yang hal tersebut tidak bisa diperbaiki (misalnya) dengan ditambal, atau dilebur dengan api untuk dibentuk ulang dari awal.

Untuk menuju kesana, al-Ghazali mulai menyelami dan memahami secara mendalam satu persatu dari empat golongan itu. Dia mengawali dengan ilmu kalam, filsafat, ajaran-ajaran batiniyah, dan terakhir melalui jalan (tariqah) tasawuf. ${ }^{1}$

\section{Ilmu Kalam (Teologi)}

al-Ghazali sebenarnya tertarik dengan disiplin ilmu ini. Ini dibuktikan dengan karya yang ia tulis tentang ilmu teologi. Namun, sebagaimana pengakuan al-Ghazali sendiri, bahwa ia tidak mendapatkan manfaat apa-apa dari teologi, kecuali manfaat itu kembali pada teologi itu sendiri. Sebab, pada perkembangan selanjutnya, disiplin ilmu teologi sudah tidak lagi terfokus pada

\footnotetext{
1 Abu Hamid Muhammad bin Muhammad al-Ghazali, al-Munqiz min al-Dhalal wa al-Mufsih bi al-Ahwal, (Beirut: Dar al-Minhaj, 2013), Cet.I, 54
} 
wilayah kajiannya; pembahasannya terlalu melebar kemanamana; dan mulai melenceng dari tujuan.

Padahal, kata al-Ghazali, tujuan ilmu teologi adalah menjaga dan membentengi akidah ahlussunah wal jama'ah dari pengaruh ahli bid'ah (hifdzu aqidah ahlissunah wa hirasatuha an tasywisi ahli al-bid'ah). Sebab, Allah SWT melalui lisan Rasul sudah menyampaikan akidah yang benar demi kemaslahatan dunia maupun akhirat (agama). Hanya saja, akidah itu kemudian tercemari oleh kehadiran ahli bid'ah. Dalam konteks ini, teologi muncul untuk memurnikan kembali akidah yang sudah tercemar itu, mengembalikan pada asalnya.

Tetapi, yang terjadi justeru tidak sesuai dengan apa yang diharapkan dan dicita-citakan. Wacana yang dikembangkan dalam teologi malah bertitik-tolak dari dasar pikiran/asumsi/hipotesis (muqaddimat) lawan. Disamping itu, para teolog (mutakallimun) lebih banyak berapologi menanggapi tuduhan-tuduhan lawan, ketimbang membicarakan esensi teologi itu sendiri.

Pada akhirnya para teolog tidak lagi membela sunnah, dan justru tenggelam dalam pembahasan tentang zat/substansi (al-jawhar), sifat/aksiden ( 'arad), dan sebagainya. Hal ini, kata alGhazali, yang menyebabkan teologi melenceng jauh dari tujuan mulianya (ghayah al-quswa). Dengan sangat kecewa al-Ghazali akhirnya tidak begitu suka dengan ilmu ini. (falam yakun alkalam fi haqqi kaafiyan, wala lidąi alladzi kuntu asykuuhu 
syafiyan) (bagiku, ilmu kalam tidak mencukupiku. Ia tidak dapat menyembuhkan penyakit keragu-raguanku). ${ }^{1}$

\section{Filsafat}

al-Ghazali belajar dan mendalami filsafat kurang lebih selama dua tahun. Ia banyak membaca kitab-kitab filsafat yang dikarang filosof muslim pada waktu itu. Dari hasil bacaannya itu, al-Ghazali menyimpulkan ada tiga mazhab besar dalam filsafat: (1) al-duhriyyun, (2) thabi'iyyun, dan (3) ilahiyyun. ${ }^{2}$

Pertama, al-duhriyyun (atheisme). Ia merujuk pada aliran filsafat kuno yang tidak mempercayai adanya Tuhan. Menurut aliran ini, kehidupan dunia ada dengan sendirinya melalui proses alam. Manusia tercipta dari sperma, begitu juga sebaliknya. Proses alam akan terus berjalan sesuai dengan hukumnya. Dan terus berjalan tanpa mengenal akhir.

Kedua, thabi'iyyun (naturalisme). Aliran filsafat yang lebih banyak membahas gejala dan perubahan materi; fenomena alam berikut makhluk hidup dan tumbuh-tumbuhan. Objek penelitiannya lebih banyak dicurahkan untuk memahami struktur tubuh mahkluk hidup. Aliran ini masih percaya terhadap adanya Tuhan.

Mereka berpendapat bahwa kekuatan yang dimiliki manusia dihasilkan oleh struktur tubuhnya, bukan disebabkan

1 Ibid., 57

2 Ibid., 61 
sesuatu yang lain yang berada diluar tubuh. Mereka juga menolak adanya dualisme jiwa dan badan. Jiwa tidak lain dari materi (badan) itu sendiri. sehingga, ketika seseorang mati, maka jiwanya juga ikut mati. Mereka tidak mempercayai adanya dunia adikodrati, seperti surga, neraka, kiamat, hisab, dan lain-lain.

Dan ketiga, ilahiyyun (metafisika). Socrates, Plato, dan Aristoteles adalah sederetaan filsuf yang masuk dalam kelompok ini. Plato adalah Murid Socrates, sedangkan Aristoteles adalah murid Plato. Aristoteles dikenal sebagai pencetus ilmu mantiq (logika), dan banyak memberikan ulasan, komentar, dan penyempurnaan terhadap pelbagai disiplin ilmu. Aristoteles juga banyak mengkritik mazhab -mazhab filsafat sebelumnya, seperti duhriyyun dan thabi'iyyun. ${ }^{1}$ Menurut al-Ghazali, secara garis besar, kajian filsafat meliputi: matematika (riyadliyyah), logika (mantiqiyyah), ilmu alam (thabi'iyyah), metafisika (ilahiyyah), politik (siyasiyyah), dan etika (khuluqiyyah). ${ }^{2}$

Pada prinsipnya, al-Ghazali tidak begitu antipati terhadap filsafat. Sebab, menurutnya, filsafat sama sekali tidak memiliki relasi dengan agama. Hanya saja, kata al-Ghazali, tidak sedikit paham/ajaran filsafat yang dapat menimbulkan efek membahayakan (afat al-adzimah) bagi keimanan, dan bahkan bertentangan dengan ajaran agama.

Sebagaimana mazhab duhriyyun yang mengingkari

\footnotetext{
1 Abu Hamid Muhammad bin Muhammad al-Ghazali, al-Munqiz min al-Dhalal wa al-Mufsih bi al-Ahwal, (Beirut: Dar al-Minhaj, 2013), Cet.I, 63

2 Ibid., 64
} 
adanya Tuhan dan thabi'iyyun yang tidak mempercayai keberadaan "dunia lain". Begitu juga ajaran ilahiyyun yang ditransfer dari Ibnu Sina dan al-Farabi yang mengatakan bahwa jasad tidak akan menerima nikmat maupun siksaan. Yang mendapatkan balasan di akherat kelak hanyalah ruh. Mereka juga mengatakan bahwa alam bersifat qadim dan abadi. ${ }^{1}$

\section{Mazhab al-Ta'limi}

Pada masa al-Ghazali hidup, mazhab ta'limiyyah atau aliran batiniyyah sedang mengalami perkembangan yang cukup pesat. Ta'limiyyah adalah salah satu aliran/sekte Syiah Ismailiyyah. Aliran ini berpendapat bahwa "setiap orang butuh pengajaran (al-ta'lim) dan bimbingan mu'allim (guru) yang ma'shum, suci terlindungi dari dosa (al-hajat ila al-ta'lim wa almua'allim. La yashluhu kullu mu'allim bal la budda min mu'allim al-ma'shum)".

Menurut sekte ini, keberadaan mu'allim ma'shum mutlak diperlukan. Sebab, tanpa melalui kehadiran mereka, seseorang tidak mungkin akan sampai pada "kebenaran". Muallim ma'shum yang dimaksudkan mereka adalah para imam (pemimpin) mereka.

Ajaran seperti ini mendapat kritik keras dari al-Ghazali. Menurutnya, tidak seorang pun di dunia ini yang layak dikatakan ma'shum kecuali Nabi Muhammad SAW. Setiap orang bebas melakukan ijtihad dalam mengambil keputusan hukum (istinbath

${ }^{1}$ Ibid., 70 
al-ahkam), tidak harus menunggu wangsit dari imam ma'shum, tegas al-Ghazali.

Al-Ghazali mengutip kisah dari Mu'adz bin Jabal ketika diutus Nabi ke Yaman. Mu'adz melakukan ijtihad sendiri ketika menemukan persoalan-persoalan yang hukumnya tidak ditemukan di dalam nash (al-Qur'an dan Hadis). Lebih lanjut, alGhazali mengatakan: "keterbatasan nash tidak akan bisa mengikuti realitas yang terus mengalami perubahan (fainna alnushus al-mutanahiyah la tastau'ibu al-waqai' al-ghaira almutanahiyyah)". 1

\section{Ilmu Tasawuf}

Setelah al-Ghazali merasa kecewa dengan ilmu-ilmu di atas, kemudian ia berpaling pada tasawuf. Untuk mengetahui hakikat tasawuf yang sesungguhnya, al-Ghazali belajar dan membaca kitab-kitab yang dikarang ulama-ulama tasawuf terkemuka. Beliau membaca Qut al-Qulub karya Abi Thalib alMakki, karya-karya al-Junaidi, al-Syibli, Abu Yazid al-Bustami, Harits al-Muhasibi dan lain-lain. ${ }^{2}$

Lagi-lagi al-Ghazali harus menelan kekecewaan. Ternyata kitab-kitab yang ia baca hanya menyuguhkan wacana tentang tasawuf. Menurut keyakinannya, inti tasawuf bukan hanya pada teorinya (ilmu/wacana) melainkan pada aplikasinya

1 Abu Hamid Muhammad bin Muhammad al-Ghazali, al-Munqiz min al-Dhalal wa al-Mufsih bi al-Ahwal, (Beirut: Dar al-Minhaj, 2013), Cet.I, 83

2 Ibid., 92 
(amaliyyah). Substansi tasawuf terletak pada pengamalan (alahwal), rasa (al-dzauq), serta suluk dan suhbah dengan para sufi. Mereka adalah orang-orang yang siapa saja mau berkumpul tidak akan sia-sia perkumpulannya (fahum qaumun la yasyqa bihim jalisuhum) ${ }^{1}$

Dari sini al-Ghazali tergerak untuk mengamalkan ajaranajaran tasawuf, ber-suhbah dengan para sufi, mengasingkan diri (uzlah) dari satu tempat ke tempat lain, menyepi (khalwah) dan mengunci diri di menara masjid Damaskus, tafakkur (kontempelasi) di menara Bait al-Maqdis, melakukan ibadah Haji, dan ziarah ke makam Rasulullah SAW. Sampai akhirnya beliau merasa bahwa dahaga intelektual-spiritualnya betul-betul hilang berkat mukasyafah dan dzauq. $^{2}$

\section{Melacak Epistemologi al-Ghazali dalam Munqidz min al-Dhalal}

Epistemologi bisa diibaratkan sebagai pintu masuk untuk mengetahui paradigma berpikir atau gugusan pemikiran seseorang. Dengan menyusuri epistemologi seseorang, akan membantu dan mempermudah membaca alur pikir atau sistematika pemikirannya dari awal sampai akhir.

Secara leksikal, Epistemologi berasal dari kata episteme (pengetahuan, ilmu pengetahuan) dan logos (informasi). Secara

\footnotetext{
${ }^{1}$ Ibi.,100-101

2 al-Ghazali bercerita panjang lebar mengenai proses yang dijalaninya ini. Lihat lengkapnya pada halaman 92-102
} 
sederhana epistemologi berarti "teori pengetahuan" atau "pengetahuan tentang pengetahuan". ${ }^{1}$

Epistemologi melahirkan beragam metode dan pendekatan. Diantara keberagaman metode dan pendekatan itu, yang paling populer adalah empirisme dan rasionalisme. Selain kedua pendekatan ini, dalam filsafat Islam juga dikenal pendekatan intuitif (irfani). Tampaknya, dalam memperoleh hakikat kebenaran (al-haq) dan pengetahuan yang hakiki (al-ilm al-yaqin), al-Ghazali menggunakan pendekatan irfani.

Jika melihat runtutan pengalaman dan perjalanan intelektual-spiritual al-Ghazali sebagaimana dia ceritakan sendiri dalam kitabnya, maka akan ditemukan bahwa pada akhirnya, pendekatan irfani yang mampu menghantarkan kepada kebenaran yang sejati dan pengetahuan yang hakiki.

Hal ini tidak dimaknai bahwa al-Ghazali tidak menggunakan nalar bayani maupun burhani, karena baginya, dua nalar itu telah selesai dan final. Ia telah banyak menghasilkan karya dari berbagai bidang ilmu melalui kedua nalar ini. Namun, pada akhirnya alGhazali merasa tidak puas dengan apa yang telah dia hasilkan dan upayakan selama ini, alih-alih memperoleh kepuasan spiritual dan ketenangan batin. Teologi dan filsafat tak mampu membawanya kepada kebenaran dan keyakinan sejati, karena dua cabang ini berlandaskan pada aspek-aspek bayani dan burhani. Justru ia berhasil

1 Bagus Lorens, Kamus Filsafat, (Jakarta: PT. Gramedia Pustaka Utama, 2007), 212 
menemukan ketenangan melalui tasawuf, yang lebih menekankan aspek-aspek irfani.

\section{Epilog}

Kitab al-Munqiz min al-Dhalal merupakan buku otobiografi al-Ghazali. Di dalamnya ia menjelaskan secara detail bagaimana proses yang ia tempuh dalam mencari kebenaran dan pengetahuan yang hakiki. Untuk menuju ke sana al-Ghazali telah mencoba melalui berbagai macam ilmu dan pendekatan, mulai dari ilmu kalam hingga filsafat, pendekatan empirikal hingga rasional, nalar bayani hingga burhani. Namun al-Ghazali merasa tidak mampu mencapai kepada kebenaran dan pengetahuan yang hakiki, kecuali pada saat ia menguunakan nalar irfani dengan menapaki (suluk) jalan (tariqah) tasawuf, serta bergaul (suhbah) dengan kalangan sufi.

\section{DAFTAR PUSTAKA}

al-Ghazali, Abu Hamid Muhammad bin Muhammad, al-Munqiz min al-Dhalal wa al-Mufsih bi al-Ahwal,(Beirut: Dar al-Minhaj, 2013)

Lorens, Bagus, Kamus Filsafat, (Jakarta: PT. Gramedia Pustaka Utama, 2007) 